\title{
Cervical Pap smear study and detection of abnormal epithelial lesions and determination of its accuracy by cytohistological correlation in patients of tertiary care teaching hospital in central India
}

\author{
Garima Malpani*, Purti Agrawal, Amit V. Varma, Nikita Khandelwal, Gargi Tignath
}

Department of Pathology, Sri Aurobindo Institute of Medical Sciences, Indore, Madhya Pradesh, India

Received: 16 May 2016

Accepted: 07 June 2016

*Correspondence:

Dr. Garima Malpani,

E-mail: dr.garima@ymail.com

Copyright: (c) the author(s), publisher and licensee Medip Academy. This is an open-access article distributed under the terms of the Creative Commons Attribution Non-Commercial License, which permits unrestricted non-commercial use, distribution, and reproduction in any medium, provided the original work is properly cited.

\begin{abstract}
Background: Cervical cancer is the second most common cancer in females and is a major cause of morbidity and mortality. Pap smear is simple, cost effective and sensitive tool for screening of various non-neoplastic and neoplastic lesions of cervix. The objective of this study was to determine the pattern of various cervical smear abnormalities in our center, to study the prevalence of epithelial cell abnormalities in our study population and to determine the accuracy of Pap test by correlating with histopathology.

Methods: This was a retrospective study of 7127 cervical pap smears screened and reported at department of pathology, Sri Aurobindo institute of medical sciences Indore, Madhya Pradesh, India during the period of January 2013 to December 2015. Pap smear was done by the conventional method and reporting was done based on the Bethesda system .Emphasis was put on epithelial cell abnormalities and the findings of abnormal epithelial lesions were correlated with histopathology.

Results: In this study, the epithelial cell abnormalities constituted $2 \%$ of all cases. Low grade squamous intraepithelial lesion was the most common epithelial cell abnormality found in our study group followed by HSIL and then squamous cell carcinoma. About two thirds of the abnormal epithelial lesions were found in the age group above 40 years. Our cytological diagnosis correlated well with histopathology.

Conclusions: Pap smear is a cost effective and sensitive screening method for detection of cancerous, pre-cancerous and non-cancerous lesions of cervix.
\end{abstract}

Keywords: Pap smear, Screening, Epithelial cell abnormalities

\section{INTRODUCTION}

According to WHO (world health organisation), Cervical cancer is the second most common cancer in females and is a major cause of morbidity and mortality. ${ }^{1}$ Global report published by WHO in 2014, shows that around $2,66,000$ women died from cancer of cervix in the year $2012 .^{2}$ Therefore this cancer is taking a toll on the health of women worldwide.
Among the South-Asian countries, India has the highest age standardization incidence of cervical cancer at 22 , compared to 19.2 in Bangladesh, 13 in Sri lanka and 2.8 in Iran. So it is very important to understand the epidemiological pattern and diagnose cervical cancers at an early stage. ${ }^{3}$

Pap smear is a simple, safe, non-invasive and cost effective method for the detection of pre-cancerous, cancerous and benign lesions of cervix. ${ }^{4}$ It is a sensitive test for early screening of cervical lesions and most 
widely and accepted system for reporting of pap smears is TBS (2001, The Bethesda system). ${ }^{5}$ With the use of pap smear as a screening tool for the detection of abnormal epithelial lesions in cervix, more cases can be diagnosed early and thus the morbidity and mortality of patients can be decreased.

This study was conducted to study the pattern of various cervical smear abnormalities in our centre, to study the prevalence of epithelial cell abnormalities in our study population and to determine the accuracy of Pap test by correlating with histopathology.

\section{METHODS}

The retrospective study was carried out at Sri Aurobindo institute of medical sciences, Indore during the period of January 2013 to December 2015. All sexually active women who attended gynecology OPD including those who had complaints of bleeding per vaginum, foul smelling whitish vaginal discharge or something coming out of vagina included in study. Unmarried females, pregnant women and already diagnosed cases of cervix carcinoma were excluded in study. A detailed history and symptoms along with parity and last menstrual period were recorded by the concerned gynaecologists and Pap smears made were sent to pathology laboratory for examination. Smears were taken by residents of gynecology department by modified ayres wooden spatula. Sampling of both ectocervix and endocervix was done. Smear was prepared, properly labeled, fixed in 95\% ethyl alcohol immediately and sent to pathology department SAIMS for pap staining. After staining slides were mounted with DPX, screened and reported by pathologist according to 2001, Bethesda system.

\section{RESULTS}

A total of 7127 smears were studied during January 2013 to December 2015 retrospectively. Out of these 7127 smears 62 were inadequate or unsatisfactory due to $\mathrm{blood} /$ mucus and were excluded from our study.

Table 1: Age wise distribution of various lesions of cervix.

\begin{tabular}{|llllllll|}
\hline Age group (years) & $\mathbf{1 5 - 3 0}$ & $31-40$ & $\mathbf{4 1 - 5 0}$ & $\mathbf{5 1 - 6 0}$ & $\mathbf{6 1 - 7 0}$ & $>\mathbf{7 1}$ & Total \\
\hline NILM & 2355 & 2667 & 1384 & 347 & 130 & 38 & $6921(97.96 \%)$ \\
\hline ASCUS & 03 & 12 & 12 & 03 & 00 & 00 & $30(0.42 \%)$ \\
\hline LSIL & 00 & 15 & 18 & 04 & 03 & 00 & $40(0.57 \%)$ \\
\hline HSIL & 02 & 13 & 17 & 04 & 02 & 00 & $38(0.54 \%)$ \\
\hline SCC & 00 & 00 & 05 & 24 & 05 & 00 & $34(0.48 \%)$ \\
\hline Adenocarcinoma & 00 & 00 & 01 & 01 & 00 & 00 & $02(0.03 \%)$ \\
\hline Total & $\mathbf{2 3 6 0}$ & $\mathbf{2 7 0 7}$ & $\mathbf{1 4 3 7}$ & $\mathbf{3 8 3}$ & $\mathbf{1 4 0}$ & $\mathbf{3 8}$ & $\mathbf{7 0 6 5}(\mathbf{1 0 0 \%})$ \\
\hline
\end{tabular}

Table 2: Age wise distribution of various non-neoplastic lesions of cervix.

\begin{tabular}{|llllllll|}
\hline Age group (years) & $\mathbf{1 5 - 3 0}$ & $\mathbf{3 1 - 4 0}$ & $\mathbf{4 1 - 5 0}$ & $51-60$ & $\mathbf{6 1 - 7 0}$ & $>71$ & Total \\
\hline Inflammatory & 1750 & 2130 & 1049 & 198 & 42 & 21 & $5190(74.99 \%)$ \\
\hline Bacterial vaginosis & 250 & 265 & 134 & 28 & 06 & 01 & $684(9.88 \%)$ \\
\hline Candidiasis & 15 & 6 & 03 & 01 & 01 & 0 & $26(0.38 \%)$ \\
\hline Trichomonas & 19 & 32 & 13 & 03 & 00 & 00 & $67(0.97 \%)$ \\
\hline Atrophy & 00 & 07 & 45 & 77 & 57 & 10 & $196(2.83 \%)$ \\
\hline Normal & 321 & 227 & 140 & 40 & 24 & 06 & $758(10.95 \%)$ \\
\hline Total & $\mathbf{2 3 5 5}$ & $\mathbf{2 6 6 7}$ & $\mathbf{1 3 8 4}$ & $\mathbf{3 4 7}$ & $\mathbf{1 3 0}$ & $\mathbf{3 8}$ & $\mathbf{6 9 2 1 ( \mathbf { 1 0 0 \% } )}$ \\
\hline
\end{tabular}

Most of the patients $(97.96 \%)$ were categorised into NILM (negative for intraepithelial lesion or malignancy) followed by LSIL (low grade squamous intraepithelial lesion) and HSIL (high grade squamous intraepithelial lesion) (Table 1). Distribution of NILM cases in subcategories has depicted in Table 2. Non-specific inflammation was the commonest finding in NILM. Among the five organisms, we found bacterial vaginosis [Figure 1(a)] in 9.88\% cases, trichomonas [Figure 1(b)] in $0.97 \%$, and candida [Figure 1(c) and 1(d)] in $0.38 \%$ cases of total NILM cases.
Epithelial cell abnormalities in cytological examination were found in total 144 cases constituting 2.04\%. Among epithelial cell abnormalities, LSIL [Figure 2(a)] was the commonest (40 cases, $0.57 \%$ ) followed by HSIL [Figure 2(b)] (38 cases, 0.54\%) and squamous cell carcinoma (SCC) (34 cases, 0.48\%) [Figure 2(c)]. We also reported 2 cases of adenocarcinoma in pap examination [Figure 2(d)]. 


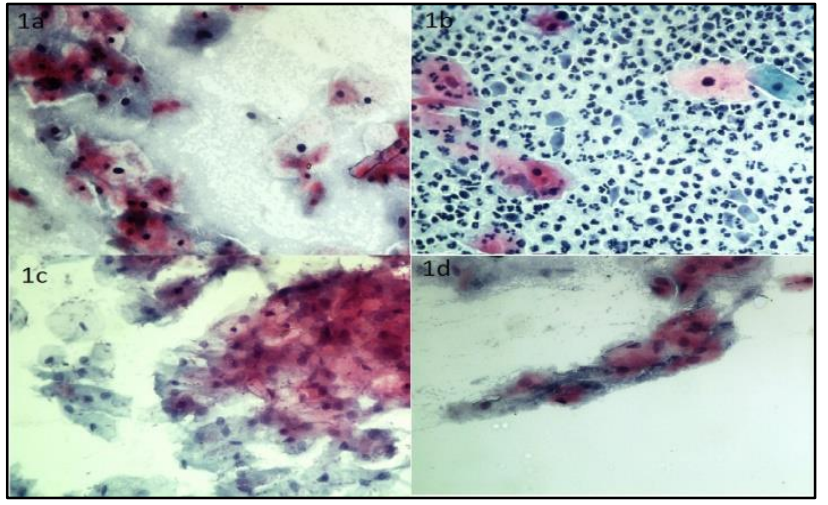

Figure 1: Photomicrograph of various organisms of NILM category; (a) altered flora with many cocobacilli and clue cells (Pap stain, X400); (b) pear shaped trichomonas (Pap stain, X400);

(c) Round to oval budding yeast forms of candida (Pap stain, X400); (d) pseudohyphae of candida (Pap stain, X400).

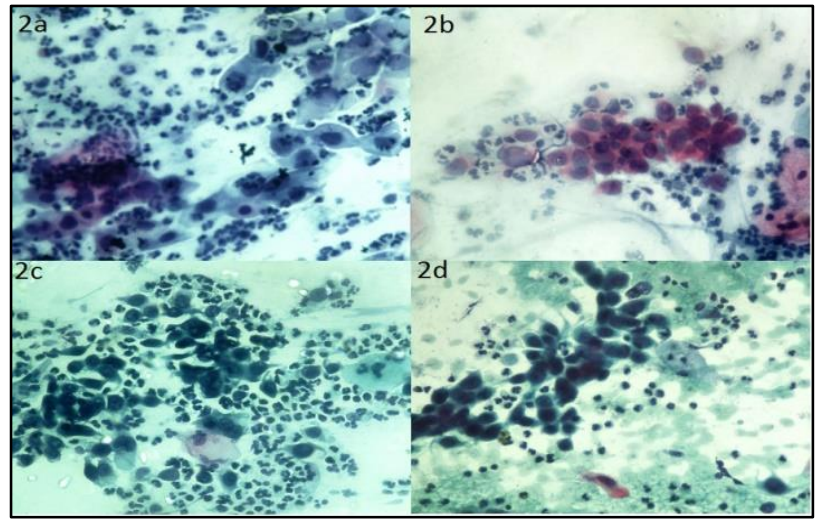

Figure 2: Photomicrograph of epithelial abnormalities in Pap smear examination; (a) LSIL (Pap stain, X400); (b) HSIL (Pap stain, X400); (c) SCC (Pap stain, X400); (d) Adenocarcinoma (Pap stain, X400).

Table 3: Correlation of Pap smear and histopathological diagnosis.

\begin{tabular}{llllllll|}
\multirow{2}{*}{ Pap smear finding } & \multicolumn{7}{c|}{ Histopathological finding } \\
& Chronic cervicitis & CIN I & CINII & CINIII/CIS & SCC & Adenocarcinoma & Total \\
\hline ASCUS & 11 & 15 & 02 & -- & - & - & 28 \\
\hline LSIL & 03 & 20 & 11 & 06 & - & - & 40 \\
\hline HSIL & 01 & 02 & 16 & 15 & 04 & - & 38 \\
\hline SCC & - & - & - & 02 & 32 & - & 34 \\
\hline Adenocarcinoma & - & - & - & -- & - & 02 & 02 \\
\hline Total & $\mathbf{1 5}$ & $\mathbf{3 7}$ & $\mathbf{2 9}$ & $\mathbf{2 3}$ & $\mathbf{3 6}$ & $\mathbf{0 2}$ & $\mathbf{1 4 2}$ \\
\hline
\end{tabular}

Age of patients ranged from 15-85 years in our study. Majority of the cases of inflammation was seen in the reproductive age group. Malignancy was more common after the age of 50 years (30 cases out of total 36 cases of malignancy) and intraepithelial lesions/dysplasia was seen mostly in the age group of 41-50 years.

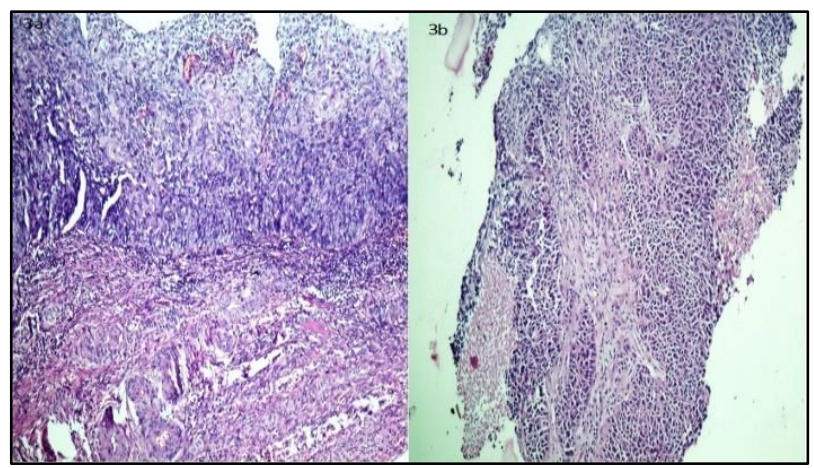

Figure 3 (a): Photomicrograph of severe dysplasia in whole thickness without invasion (H and E, X100); (b) photomicrograph of non-keratinizing squamous cell carcinoma of cervix ( $H$ and $\mathrm{E}, \mathrm{X100})$.
In our study we also followed up the cases of epithelial cell abnormalities for histopathology. Out of total 144 cases we got biopsy/hysterectomy specimens in 142 cases. Correlation of pap finding with histopathology was shown in Table 3. According to Bethesda 2001 classification LSIL on cytology is histologically equivalent to mild dysplasia/CIN1. Similarly HSIL histologically equivalent to moderate and severe dysplasia, CIN2, CIN3 and carcinoma in situ (CIS) [Figure 3(a)]. Thus concordance rate for different lesions was calculated and given below;

Histological diagnosis

Concordance rate

LSIL

$54.05 \%$

HSIL

$59.62 \%$

SCC

$88.89 \%$

Adenocarcinoma

$100 \%$

Statistical values of pap smear for different abnormal epithelial lesions are given in Table 4. Pap smear was least sensitive in diagnosing LSIL (54.05\%) but specificity $(80.95 \%)$ and diagnostic accuracy was good. (73.94\%). Overall sensitivity, specificity, positive predictive value (PPV), negative predictive value (NPV) 
and diagnostic accuracy of Pap smear in diagnosing cervical dysplasia and malignancy were $86.61 \%, 73.33 \%$, $96.49 \%, 39.29 \%$ and $85.21 \%$ respectively.

Sensitivity, Specificity and diagnostic accuracy was moderately good, PPV was very good but NPV was low in our study.

Table 4: Statistical values of Pap smear for different abnormal epithelial lesions in percentage.

\begin{tabular}{|lllll|}
\hline Particulars & LSIL & HSIL & SCC & Adenocarcinoma \\
\hline Sensitivity & 54.05 & 59.62 & 88.89 & 100 \\
\hline Specificity & 80.95 & 92.22 & 98.11 & 100 \\
\hline PPV & 50 & 81.58 & 94.12 & 100 \\
\hline NPV & 83.33 & 79.81 & 96.30 & 100 \\
\hline $\begin{array}{l}\text { Diagnostic } \\
\text { accuracy }\end{array}$ & 73.94 & 80.28 & 95.77 & 100 \\
\hline
\end{tabular}

$\mathrm{P}$ value $<0.0001$

Table 5: Comparison of overall statistical parameters with other studies.

\begin{tabular}{|llllll|}
\hline Study & $\begin{array}{l}\text { Sensitivity } \\
(\%)\end{array}$ & $\begin{array}{l}\text { Specificity } \\
(\%)\end{array}$ & $\begin{array}{l}\text { PPV } \\
(\%)\end{array}$ & $\begin{array}{l}\text { NPV } \\
(\%)\end{array}$ & $\begin{array}{l}\text { Diagnostic } \\
\text { accuracy } \\
(\%)\end{array}$ \\
\hline Saha et al $^{12}$ & 76 & 83.3 & 86.4 & 71.4 & 79.1 \\
\hline $\begin{array}{l}\text { Mallur P } \\
\text { et al }^{16}\end{array}$ & 41.66 & 81.2 & 86.21 & 78.26 & 40 \\
\hline Jain et al $^{13}$ & 78 & 26.9 & 91 & 11.3 & 73.2 \\
\hline $\begin{array}{l}\text { Ashmita } \\
\text { et al }\end{array}$ & 19.51 & 83.33 & 80.00 & 86.54 & 23.26 \\
\hline $\begin{array}{l}\text { Chaudhary R } \\
\text { et al }\end{array}$ & 25.40 & 99.27 & 94.12 & 74.32 & 76 \\
\hline Naik R et al & 79.4 & 58.3 & 86.1 & 46.6 & 74.5 \\
\hline $\begin{array}{l}\text { Present } \\
\text { study }\end{array}$ & 86.61 & 73.33 & 96.49 & 39.29 & 85.21 \\
\hline
\end{tabular}

\section{DISCUSSION}

According to national cancer registry program of India, cancers of uterine cervix and breast are the leading malignancies in Indian women. ${ }^{5}$ There should be an effective mass screening programme for earlier detection of precancerous conditions specially in the high risk age group so that their treatment can be started earlier and morbidity and mortality rated can be reduced.

\section{Cytological findings in different age groups}

About $65 \%$ of the total cases are above the age of 30 years in our study. Our finding is similar to a study by Ranabhat et al who got $76 \%$ of his total cases above 30 years age. ${ }^{6}$ This supports that cervical screening is delayed by many years in majority of females in India. There is a need for educating the people and increasing awareness about the benefits of early pap smear testing by conducting regular education programs. Moreover, the physicians and healthcare professionals should also motivate and educate the general public regarding pap testing.
The majority cases of malignancy were seen in the age group of 51-60 years and cases of intraepithelial lesion was seen mostly in the age group of 41-50 years. Our finding is similar to Naik et al who reported the same age group for malignancy and intraepithelial lesion. ${ }^{3}$ Even Ranabhat et al reported that eighty percent of all epithelial cell abnormalities were found in the age group $>40$ years of age. ${ }^{6}$

Among all the NILM lesions, inflammatory lesion was the most common diagnosed condition which covered almost three fourth cases $(73.46 \%)$. Majority of the cases of inflammation was seen in the age group of 31-40 years. Our finding similar to Naik et al study which reported the same figures. However Mulay et al found $19.6 \%$ cases of non-specific inflammation in Indian study group and $25.34 \%$ in the Mauritian group. ${ }^{3,7}$ Ranabhat et al found $26 \%$ cases of non-specific inflammation in their study which is very low as compared to our study. ${ }^{6}$

Among all the infections diagnosed bacterial vaginosis was most common as seen with other study. ${ }^{6}$

\section{Epithelial cell abnormalities}

In our study there were 144 cases $(2.04 \%)$ of abnormal epithelial lesions. Our finding similar to Ranabhat et al who has reported prevalence of $1.7 \%$. The prevalence of epithelial cell abnormalities around the world has a wide range of $0.98 \%$ to as high as $15.5 \% .^{6}$ The percentage of epithelial abnormalities have ranged from 2.3 to $6.6 \%$ in US, $1.6 \%$ to $7.9 \%$ in the middle east, $0.98 \%$ to $4.41 \%$ in Israel and $1.87 \%$ to $5.9 \%$ in India. ${ }^{7}$ The reason for this wide variation could be many like different criteria's used for diagnosis of lesions, the difference in the sample size studied and the difference in the prevalence of risk factors in the population studied by different groups.

In our study out of all epithelial cell abnormalities, LSIL was found to be most common followed by HSIL and then squamous cell carcinoma. Our figures are similar to study by Gupta et al who also reported LSIL to be most common epithelial cell abnormality. ${ }^{8}$ However in a study by Ranabhat et al HSIL was the most common lesion. ${ }^{6}$

\section{Cyto-histological correlation}

The overall concordance rate of the study was $86.61 \%$ which is comparable with other studies like Nawaz et al, Yeoh et al and Rasbridge et al who have reported concordance rate of $74 \%, 52 \%, 81.2 \%$ respectively. ${ }^{9-11}$ Concordance rate for SCC [Figure 3(b)] in our study was $88.89 \%$ as compared to $100 \%$ concordance rate reported by Saha et al, $97.33 \%$ by Nawaz et al and $60 \%$ by Yeoh et al. ${ }^{9,10,12}$

In our study, the overall sensitivity of pap smear was $86.61 \%$; specificity was $73.33 \%$, PPV was $96.49 \%$, NPV was $39.29 \%$ and diagnostic accuracy was $85.21 \%$. The diagnostic accuracy in our study was comparable to Naik 
et al $(74.5 \%)$, Saha et al $(79.1 \%)$, Jain et al $(73.2 \%)$ and Chaudhary et al $(76 \%))^{3,12-14}$ However, Ashmita et al and Mallur et al found lower accuracy (Table 5). ${ }^{15,16}$ This study shows a good correlation between pap smear and cervical histology. It was seen that the PPV of Pap smear was highest for malignancy. This is similar to study by Naik et al. ${ }^{3}$

\section{CONCLUSION}

Pap smear is a less invasive, cost effective and simple procedure to diagnose cervical lesions and epithelial cell abnormalities in developing country like India. Therefore periodical cytological screening helps in early detection of cervical lesions and help in reducing the morbidity and mortality associated with cervical cancer. Even the government and NGOs can help in increasing the awareness and educating the people about the screening benefits of Pap smear at an early stage.

\section{ACKNOWLEDGEMENTS}

The authors would like to thanks the technical staff of pathology department, SAIMS for processing the pap smears and cervical biopsies.

Funding: No funding sources Conflict of interest: None declared

Ethical approval: Not required.

\section{REFERENCES}

1. Joshi C, Kujur P, Thakur N. Correlation of Pap smear and colposcopy in relation to histopathological findings in detection of premalignant lesions of cervix in a tertiary care centre. International Journal of Scientific study. 2015;3:55-60.

2. Comprehensive Cervical cancer Control. A guide to essential practice. Second edition. World Health Organization 2014. Available at http://apps.who.int/iris/bitstream/10665/144785/1/97 89241548953_eng.pdf. Accessed on 12 May2016.

3. Naik R, Minj MM, Panda R, Satpathi S, Behera PK, Panda KM. Cytohistological correlation and accuracy of the pap smear test in diagnosis of cervical lesions: a hospital based cross-sectional study from Odisha, India. Medical Science. 2015;3:242-9.

4. Bodal VK, Brar RK, Bal MS, Kaur B, Kaur S, Suri $\mathrm{AK}$, et al. Correlation of Pap smear with histopathological findings in malignant and nonmalignant lesions of cervix. Global Journal of Medical Research. 2014;14:19-24.

5. Patel M, Pandya A, Modi J. Cervical Pap smear study and its utility in cancer screening to specify the strategy for cervical cancer control. National Journal of Community Medicine. 2011;2:49-51.

6. Ranabhat SK, Shrestha R, Tiwari M. Analysis of abnormal epithelial lesions in cervical pap smears in mid-Western Nepal. Journal Pathology of Nepal. 2011;1:30-3.

7. Mulay K, Swain M, Patra S, Gowrishankar S. A comparative study of cervical smears in an urban hospital in India and a population based screening program in Mauritius. Indian $\mathbf{J}$ Pathol Microbiol. 2009;52:34-7.

8. Gupta K, Malik NP, Sharma VK, Verma N, Gupta A. Prevalence of cervical dysplasia in Western Uttar Pradesh. J Cytol. 2013;30:257-62.

9. Nawaz FHAQ, Aziz AB, Parvez S, Rizvi J. Prevalence of abnormal papanicolaou smears and cyto histological correlation. A study from Aga khan university hospital, Pakistan. Asia Pacific Journal of Clinical Oncology. 2005;1:128-32.

10. Yeoh GP, Chan KW. The accuracy of papanicolaou smear predictions: cytohistological correlation of 283 cases. Hong Kong Med J. 1997;3:373-6.

11. Rasbridge S. One year Audit. Acta cytological. 2005;39:648-51.

12. Saha R, Thapa M. Correlation of cervical cytology with cervical histology. Kathmandu Univ Med J (KUMJ). 2005;3:222-4.

13. Jain V, Vyas AS. Neoplasia cyto-histological correlation (bethesda system) a study of 276 cases. J cytol Histol. 2010;1:106.

14. Chaudhary RD, Inamdar SA, Hariharan C. Correlation of diagnostic efficacy of unhealthy cervix by cytology, colposcopy and histopathology in women of rural areas. Int $\mathbf{J}$ Reprod Contracept Obstet Gynecol. 2014;3:213-8.

15. Ashmita D, Shakuntala PN, Rao SR, Sharma SK, Geethanjali S. Comparison and correlation of pap smear, coploscopy and histopathology in symptomatic women and suspicious looking cervix in a tertiary hospital care centre. Int J Health Sci Res. 2013;3:50-9.

16. Mallur PR, Desai BR, Anita D, Geeta D, Bhavana S, Pallav G. Sequential screening with cytology and colposcopy in detection of cervical neoplasia. J South Asian Feder Obst Gynae. 2009;1:45-8.

Cite this article as: Malpani G, Agrawal P, Varma AV, Khandelwal N, Tignath G. Cervical Pap smear study and detection of abnormal epithelial lesions and determination of its accuracy by cytohistological correlation in patients of tertiary care teaching hospital in central India. Int J Reprod Contracept Obstet Gynecol 2016;5:2312-6. 